\title{
The application of the Intermittent SBAS (ISBAS) InSAR method to the South Wales Coalfield, UK.
}

\author{
Luke Bateson ${ }^{1}$, Francesca Cigna ${ }^{1}$, David Boon ${ }^{2}$, Andrew Sowter ${ }^{3}$. \\ ${ }^{1}$ British Geological Survey (BGS), Keyworth, Nottinghamshire. NG12 5GU. United Kingdom. \\ ${ }^{2}$ British geological Survey (BGS), Tongwynlais, Cardiff, CF15 7NE. United Kingdom \\ ${ }^{3}$ Nottingham Geospatial Institute, University of Nottingham, Nottingham. United Kingdom \\ lbateson@bgs.ac.uk, fcigna@bgs.ac.uk, dboon@bgs.ac.uk, andrew.sowter@nottingham.ac.uk \\ Corresponding author: Luke Bateson: Ibateson@bgs.ac.uk, tel (+44)0115 9363043.
}

\section{Abstract}

Satellite radar interferometry is a well-documented technique for the characterization of ground motions over large spatial areas. However, the measurement density is often constrained by the land use, with best results obtained over urban and semi urban areas. We use an implementation of the Small Baseline Subset (SBAS) methodology, whereby areas exhibiting intermittent coherence are considered alongside those displaying full coherence, in the final result, to characterize the ground motion over the South Wales Coalfield, United Kingdom. 55 ERS-1/2 Synthetic Aperture Radar (SAR) C-band images for the period between 1992 and 1999 are processed using the ISBAS (Intermittent Small BAseline Subset) technique, which provides 3.4 times more targets, with associated measurements than a standard SBAS implementation. The dominant feature of the observed motions is a relatively large spatial area of uplift. Uplift rates are as much as $1 \mathrm{~cm} / \mathrm{yr}$. and are centred on the part of the coalfield which was most recently exploited. Geological interpretation reveals that this uplift is most likely a result of mine water rebound. Collieries in this part of the coalfield required a ground water to be pumped to enable safe coal extraction; following their closure pumping activity ceased allowing the water levels to return to equilibrium. The ISBAS technique offers significant improvements in measurement density ensuring an increase in detection of surface motions and enabling easier interpretation.

Keywords- InSAR; Intermittent SBAS; ISBAS; coal mining; Subsidence; uplift; minewater rebound.

\section{INTRODUCTION}

One of the major drawbacks of conventional Persistent Scatterer Interferometry (PSI; e.g., [10]) or Small Baseline Subset (SBAS; e.g., [2]; [18]) techniques for processing stacks of satellite Synthetic Aperture Radar (SAR) images is that generally only urban and rocky areas yield results. This can often give an incomplete view of the spatial extent of deformation and, in many cases, may not detect the deformation at all.

This paper presents results of a newly modified implementation of the SBAS processing methodology, known as Intermittent Small Baseline Subset (ISBAS), which was developed at the Nottingham Geospatial Institute of the 
University of Nottingham [30]. This technique differs from a standard SBAS approach as pixels within the input radar stack which are only coherent for subsets of the total time period to be processed are considered along with those deemed to be coherent throughout the time period processed. This approach provides greater spatial coverage and therefore a fuller picture of ground deformation patterns, and has been tested for monitoring ground motions in non-urban and rural areas of the UK, Italy and Indonesia [7][24][25][26][31], and a range of applications including landsliding, mining-related subsidence and uplift in UK coalfields, and changes in surface elevation of blanket peat.

The novel ISBAS approach has been applied to an area in South Wales covering the urban areas of Cardiff and Swansea along with much of the South Wales Coalfield, typically covered by rural land use including some small towns. This study site was chosen, with input from geologists working in the area [23] who suspect a complex history of ground deformation related to mining and post-glacial stress relief ([12][20][16]), as well as based on the nationwide InSAR (SAR Interferometry) feasibility mapping assessment carried out by the British Geological Survey (BGS) in the project "Assessing the feasibility of InSAR for nationwide monitoring of geohazards in Great Britain: first applications to landslide hazards" [5], [6], [8] . The latter showed potential for the application of InSAR techniques to monitor ground motions over the coalfield, and good likelihood to retrieve moderate to high densities of radar scatterers and coherent targets over the various land cover types of this area.

South Wales represents an area in which a relatively low measurement density would typically be expected from InSAR techniques due to the land cover, land use and topography (Figure 1b) [5], [8]. Typically InSAR ground motions derived from techniques such as SBAS and PSI show the maximum measurement density in urban areas. Urban areas in South Wales cover approximately $7 \%$ of the processed image and are largely confined to the urban centres found along the south coast, such as Cardiff and Swansea, and the mining towns found in the bottom of the deeply incised valleys to the east of the coalfield [8] . Approximately $93 \%$ of the processed area is covered by rural landuse types of which the main uses are grasslands for animal grazing, moors and heathlands and non-irrigated arable lands (Figure 1b) [13].

The BGS expect ground motions relating to elastic rebound resulting from excavation and post-mining groundwater rebound [22][12], mass movements on the steep sided valleys, and compression and consolidation of normally-consolidated Quaternary deposits and artificial deposits. Previous studies have shown similar types of motions within former coal mining areas in the UK, for instance in Stoke-on-Trent [11][17], Durham and 
Northumberland [1], and the South Derbyshire and Leicestershire Coalfields [30]), as well as overseas, for instance in south Limburg (The Netherlands) and across Germany and Belgium [9], with observed annual rates of ground uplift as high as a few centimetres per year.

This paper will present the first ISBAS results for South Wales and compare them to standard SBAS results. We will examine the relationships between the causative factors, in particular the timing of coal extraction and mine water pumping histories of these mining sites.

\subsection{Geological stratigriphy and structure of the South Wales Coalfield}

The South Wales Coalfield is an E-W trending syncline divided by a major NE-SW trending fault system (Neath Valley Disturbance), which effectively forms two sub-basins, the eastern being shallower than the western and containing two subsidiary synclines. The western crop contains high-grade Anthracite coal but is buried to up to $2 \mathrm{~km}$, thus limiting development of the coal industry to the periphery of the basin [21]. The eastern crop contains two subsidiary flexures, separated by the E-W Pontypridd Anticline, the narrow Llantwit-Caerphilly syncline in the south and the broad Gelligaer syncline to the north. Many NW-SE trending Variscan fault structures cross the basin and E-W trending low-angle thrust faults occur at the northern tip of the Variscan Trust Front in the south east

(Figure 1). The stratigraphy of the coalfield is subdivided into the South Wales Coal Measures Group overlain by the Warwickshire Group (Figure 2). The South Wales Coal Measures Group comprises the productive Middle and Lower Coal Measures with abundant coal seams intebedded with mudstones, while the Warwickshire Group features predominantly sandstones, subsidiary mudstones and minor coals at the base [15].
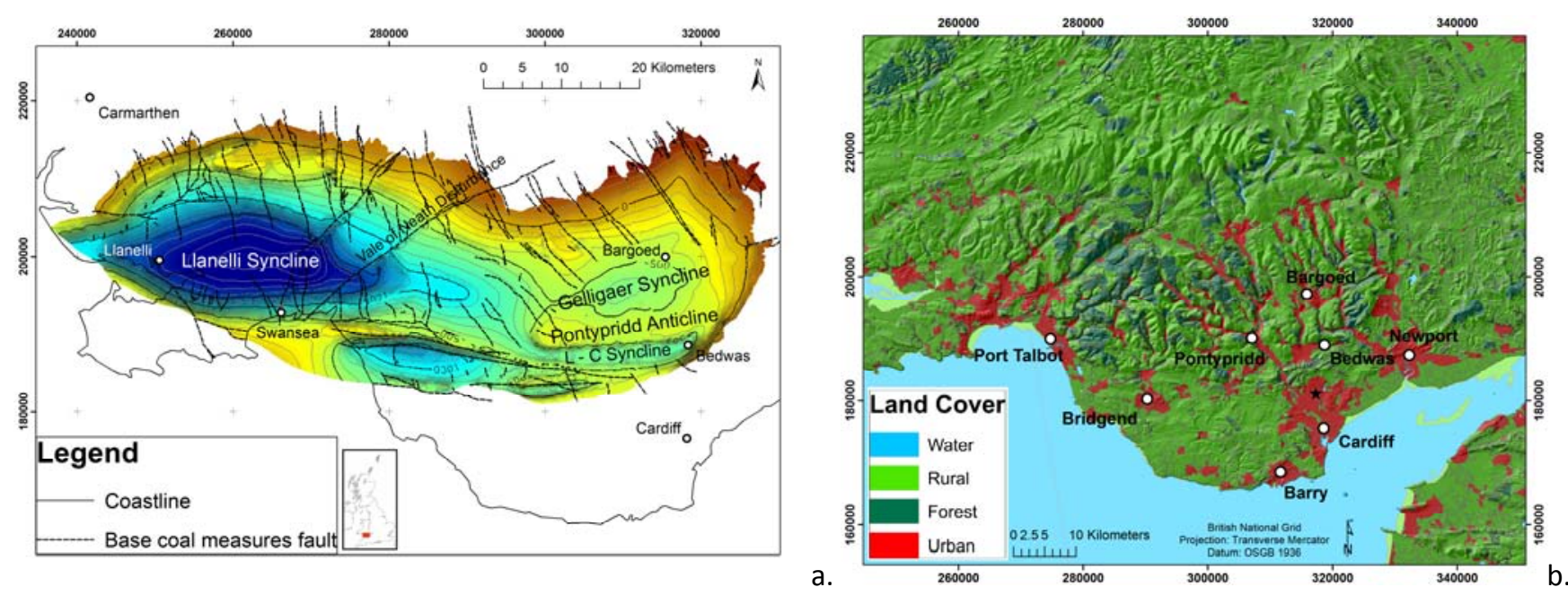
Figure 1a: Location and generalised structure of the South Wales Coalfield Basin. Blues represent the deepest part of the basin greater than $-1000 \mathrm{~m}$ asl, yellows indicate $\sim-500 \mathrm{~m}$ asl, and reds indicate shallowest part. Contains Ordnance Data C Crown Copyright and database rights 2013. Ordnance Survey Licence no. 100021290.. 1b: Topography and Land Cover of the study area, rural land cover types dominate with urban areas confined to the major urban centres and valley bottoms. (NEXTMap ${ }^{\circledR}$ Britain elevation data from Intermap Technologies, Land Cover information from CORINE land Cover map 2006 CLC2006 C 2007, European Environment Agency (EEA).

\subsection{History of coal extractionin South Wales}

Coal mining in South Wales started in Roman times expanding from the $14^{\text {th }}$ Century onwards, but grew considerably fuelling the energy demands of the Industrial Revolution in the $19^{\text {th }}$ and $20^{\text {th }}$ Centuries with peak production in 1913 when 29.8 million tons were exported from the ports of South Wales [3]. The primary coal resource areas were around the edge of the coal field (Figure 2). Initially coal was mined from shallow workings or 'bell' pits and horizontal adits or 'levels' that were driven into the hillside. In the mid-19th century shallow coal and iron ore were extracted from the basin margin to feed the then thriving iron smelting industry. Later, deep mines were sited on valleys floors enabling access to deeper coal seams in secondary coal resources areas. In the $20^{\text {th }}$ Century mass mechanization made open cast mining economically viable. The quality of coal varies across the coalfield, in the west crop (the deepest part of the coalfield) high quality anthracite was mined, while the eastern and central valleys provided a source of 'steam' coal and bituminous coal. Improvements in mining methods and development of new industries fuelled the use of lower quality 'coaking' coal from the central and eastern crops.

Following repeated miners' strikes after the First World War, nationalisation of the industry through formation of the National Coal Board in 1947, and fluctuations in the price of coal, the coal industry started to decline through the 1970's and 1980's. By the 1990s most deep mines had closed, apart from a few remaining open pits. The last deep mine, Tower Colliery, closed in 2008.

Controlling high groundwater flows proved a constant engineering challenge, particularly in the east where fractured bedrock and deep valleys allow rapid recharge of the coal measures aquifer [27]. To counter this problem ingenious pumping schemes were developed and disused deep shafts and infrastructure were commonly converted to provide ventilation for connecting collieries resulting in interconnection of some deep mines, such as Bwllfa (Figure 7). Most pumps have now been turned off allowing groundwater levels to rebound to equilibrium levels. 


\subsection{Likely ground motion mechanisms}

Extraction of shallow coal often causes local subsidence through collapse of mine workings and compression of goafs, while large scale extraction of deep coal causes regional-scale subsidence. Subsidence below slopes is also expected to cause local stress relief and dilation of rock masses in slopes [20]. Dewatering causes an increase in vertical effective stress, leading to primary and secondary consolidation of clays and mudstones, settlement and subsidence [33]. Post-extraction groundwater rebound partly reverses the situation by reducing vertical effective stress, effectively removing a surcharge, and this stress path is expected to cause minor elastic rebound and localscale uplift [22]. The re-saturation of clays or mudstones by rising ground water will also lead to swelling and volume increase or ground heave, potentially another cause of uplift. These forms of ground motion behaviour are difficult to distinguish, and expensive to measure on a regional scale using traditional topographic surveying techniques, however, new remote sensing methods, such as ISBAS, may offer a viable alternative for long-term regional-scale monitoring of shallow crustal rebound.

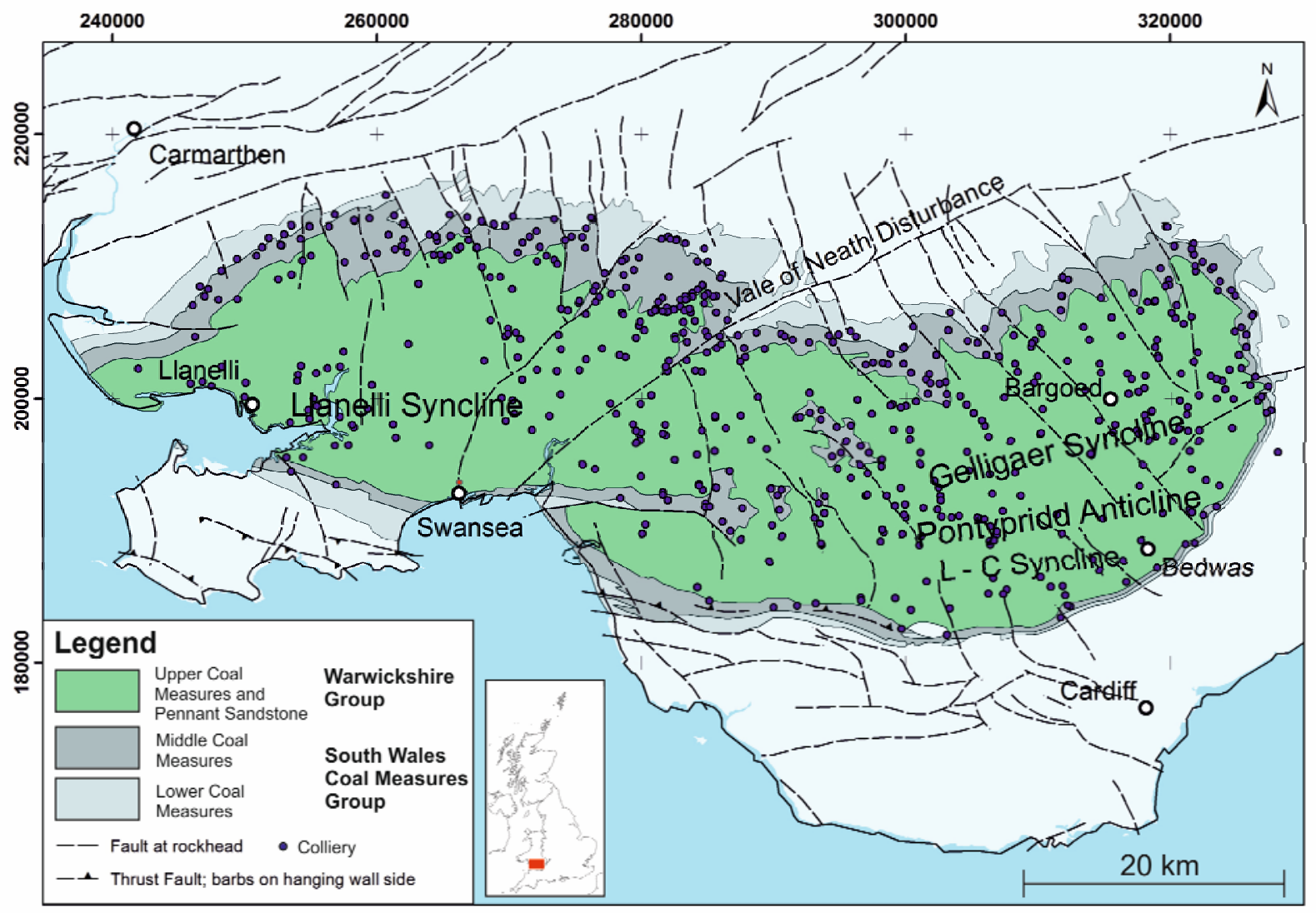


Figure 2. South Wales Coalfield geology map (modified from [15] and [21]). Contains Ordnance Data C Crown Copyright and database rights 2013. Ordnance Survey Licence no. 100021290.

ISBAS ANALYSIS OF LAND MOTIONS IN SOUTH WALES

\subsection{Input SAR imagery and pre-processing}

55 SAR images for the seven year period between 25/04/1992 and 14/12/1999 were processed, which were acquired by the C-band (i.e. $5.3 \mathrm{GHz}$ frequency, $5.6 \mathrm{~cm}$ wavelength) Active Microwave Instrument (AMI) onboard ESA's ERS-1 and ERS-2 satellites at altitudes of $\sim 800 \mathrm{~km}$ above the Earth's surface, along sun-synchronous polar orbits.

The image stack covers an area of $100 \mathrm{~km}$ by $100 \mathrm{~km}$, and the slant range and azimuth pixel spacing of the scenes are $8 \mathrm{~m}$ and $4 \mathrm{~m}$ respectively which, on the ground, correspond nominally to $\sim 25 \mathrm{~m}$ pixels. The Line Of Sight (LOS) characterizing the stack has a look angle of $23.3^{\circ}$ (with respect to vertical) referred to the centre of the scene, and the satellite ground track is tilted approximately $14^{\circ}$ with respect to the E-W direction at the latitudes of South Wales.

Though the nominal repeat cycles of ERS-1/2 SAR sensors are 35 days, meaning that the same area of interest is imaged with approximately monthly temporal frequency by each satellite, the image temporal coverage throughout the ERS-1/2 archive for the South Wales Coalfield is quite dense in 1992-1993 and 1995-1999, but a gap of 20 months exists between July 1993 and April 1995, when ERS-1 was operated in different orbits and modes (Figure 3a).

Orbit state vectors for the 55 Single Look Complex scenes were first improved and orbital errors minimized by employing the recomputed ERS-1/2 orbital data provided by the Delft Institute for Earth-Oriented Space research (DEOS), which were made available via ESA's project REAPER (Reprocessing of Altimeter Products for ERS) in 2011[28]. The image stack was then co-registered to a single master scene acquired on 25/09/1995, obtaining coregistration accuracies for the slaves as high as 0.05 pixels in range and 0.15 pixels in azimuth.

A subset of the full image frame was selected to cover the area of interest, by clipping the co-registered scenes to the range interval 500-4,800, and azimuth interval 8,500-23,500, by reducing the size of the processing area to 4,300 pixels in range, and 15,000 in azimuth, which corresponds to $\sim 5,200 \mathrm{~km}^{2}\left(\sim 4,300 \mathrm{~km}^{2}\right.$ land only, and $\sim 900 \mathrm{~km}{ }^{2}$ water) 
area on the ground (Figure 3b). Multi-looking factors of 4 and 20 were then employed to increase the phase signal quality and reduce radar speckle, and this increased the corresponding size of the image pixels on the ground to $\sim 100 \mathrm{~m}$.

The resulting average coherence of the processed subset was generally quite low, with the majority of the scene showing very low coherence values (i.e. between 0 and 0.25 ) and only built-up areas of Cardiff, Swansea, Barry and Bridgend, and several small villages along the valleys of the coalfield showing higher coherences (i.e. between 0.25 and 1; see Figure $3 b$ and Figure $4 b)$.

\subsection{ISBAS processing implementation}

Based on the 55 multi-looked scenes, a set of 271 multiple-master, small baseline interferograms was generated by employing a perpendicular baseline threshold of $200 \mathrm{~m}$, and a temporal baseline threshold of 4 years (Figure 3a), to minimize the presence of temporal and spatial phase decorrelation components in the generated interferograms and enhance phase quality of the processed pixels (hence coherence). Despite the presence of temporal gaps in the stack between 1993 and 1995, the small baselines characterizing the available scenes showed good density and level of redundancy in the resulting network of InSAR pairs across the entire monitored period, and all scenes were employed for the ISBAS analysis.

The threshold for the average coherence across all interferograms for the selection of the image pixels suitable for the conventional SBAS analysis was set to 0.25 . For the implementation of the ISBAS approach this value was used as a threshold to select coherent pixels within each interferogram, so that for each image pixel, only those interferograms showing coherence higher than 0.25 were kept for the subsequent processing steps, provided that the number of coherent layers for those pixels exceeded 50, which was used as threshold for the selection of intermittently coherent targets (see also [30]). This threshold allows a trade-off between uncertainty in the ISBAS solutions and spatial coverage of results to be adopted.

Initial topographic information for the processing area was extracted from the $90 \mathrm{~m}$ resolution Shuttle Radar Topography Mission (SRTM) Digital Surface Model (DSM) made available by NASA [14]. The reference point location to refer all ground motion estimates to was set in Cardiff at the location [51.51N, $-3.20 \mathrm{E}]$, within an area of high interferometric coherence across all small baseline interferograms that has also low susceptibility to natural geohazards, according to the BGS GeoSure dataset [34]. 
Computation of linear velocities was performed by following the methodology described by [30], and based on differential interferograms which were unwrapped by employing the SNAPHU algorithm [3]. Height errors, atmospheric components and time series were also computed using spatio-temporal filters based on the deterministic characterization of the various phase components.
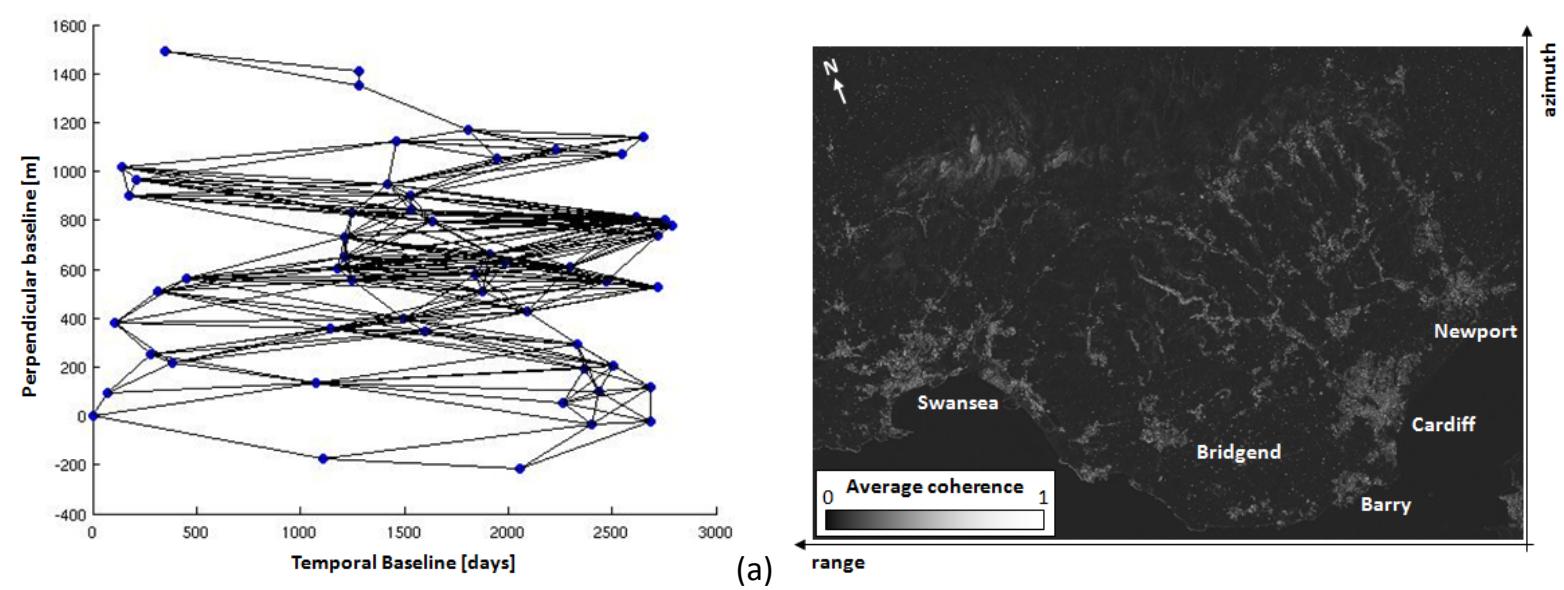

(b)

Figure 3: (a) Temporal and perpendicular baselines of the ERS-1/2 SAR image data pairs processed over South Wales; (b) average coherence for the processed image subset (in radar coordinates).

A total of 54,815 coherent pixels were identified with the SBAS approach, showing an average of $\sim 13$ points $/ \mathrm{km}^{2}$ over the entire processing area (Figure 4a). Coherent targets concentrate over the urban areas of Cardiff, Swansea, Newport and, to the north, small villages located along the valleys of the coalfield, where higher values of the average interferometric coherence were observed.

Comparison between the results obtained with the conventional SBAS and recently developed ISBAS approach show that the increase in the number and density of identified and monitored targets increased by a factor of $~ 3.4$. The ISBAS results provide a total of 190,161 targets (corresponding to $\sim 44$ points $/ \mathrm{km}^{2}$; Figure $4 \mathrm{~b}$ ).

The improvement in spatial coverage achieved using the ISBAS methodology compared to a standard implementation of SBAS is also highlighted by the increase in image pixels identified via each technique. The ISBAS results show a $21 \%$ increase in coverage of the derived ground motion information compared to SBAS. SBAS results cover $8 \%$ of the image pixels, while ISBAS cover $29 \%$, when a minimum of 50 coherent layers are used to accept a pixel in the ISBAS analysis. 
This increase represents an important additional source of information for the analysis of land motions over this rural region.

\section{SURFACE DEFORMATION IN SOUTH WALES}

Both the SBAS and ISBAS results show that with some notable exceptions, South Wales is mostly stable (Figure 4a-b). Processing targets with intermittent coherence offers a significant increase in the spatial distribution and number of points to use for the analysis (as discussed in section 3), to the detriment of the confidence in the ISBAS solution due to a lower number of coherent layers considered to extract the various components of the interferometric phase signal. Observed spatial averages of the annual motion velocity of all SBAS and ISBAS results across the processed area are +0.4 and $+0.5 \mathrm{~mm} / \mathrm{yr}$. respectively, with motion rates across the coalfield varying between -4.7 and $8.5 \mathrm{~mm} / \mathrm{yr}$. in the SBAS results, and -7.3 and $+13.1 \mathrm{~mm} / \mathrm{yr}$. in the ISBAS results. Standard deviations of the annual velocity values of the SBAS results range between 0.2 and $0.6 \mathrm{~mm} / \mathrm{yr}$. These increase to 0.9 $\mathrm{mm} / \mathrm{yr}$. on average and up to $2.9 \mathrm{~mm} / \mathrm{yr}$. for the ISBAS results, due to the lower level of certainty in the processing solutions for the intermittently coherent pixels.

Several small areas of ground subsidence are notable, particularly in Cardiff, along the low-lying coast and estuary, and Port Talbot, where development and modification of drainage has likely led to settlement of normallyconsolidated superficial deposits and artificial ground. Other areas of subsidence are present on plateaux tops and along valleys, such as near Pontypridd, where it is thought that mass movements on steep slopes and attempts to stabilise mine waste tips may contribute to the observed motion. Drainage of surface water and compression or erosion of peat bogs on upland interfluves may also present as subsidence.

By far the most striking feature of the South Wales InSAR result is the large area of uplift in the eastern valleys to the north of Cardiff. The pattern of uplift is characterised by two discrete areas of high uplift rates (Figure 4) and an area further to the west displaying a more spatially diffuse uplift pattern consisting of lower uplift rates. The areas of maximum uplift rates are seen in the Bargoed area and the Bedwas area on the north-eastern edge of the Llantwit Caerphilly syncline. In these areas uplift rates as much as $1 \mathrm{~cm} / \mathrm{yr}$. are observed. 

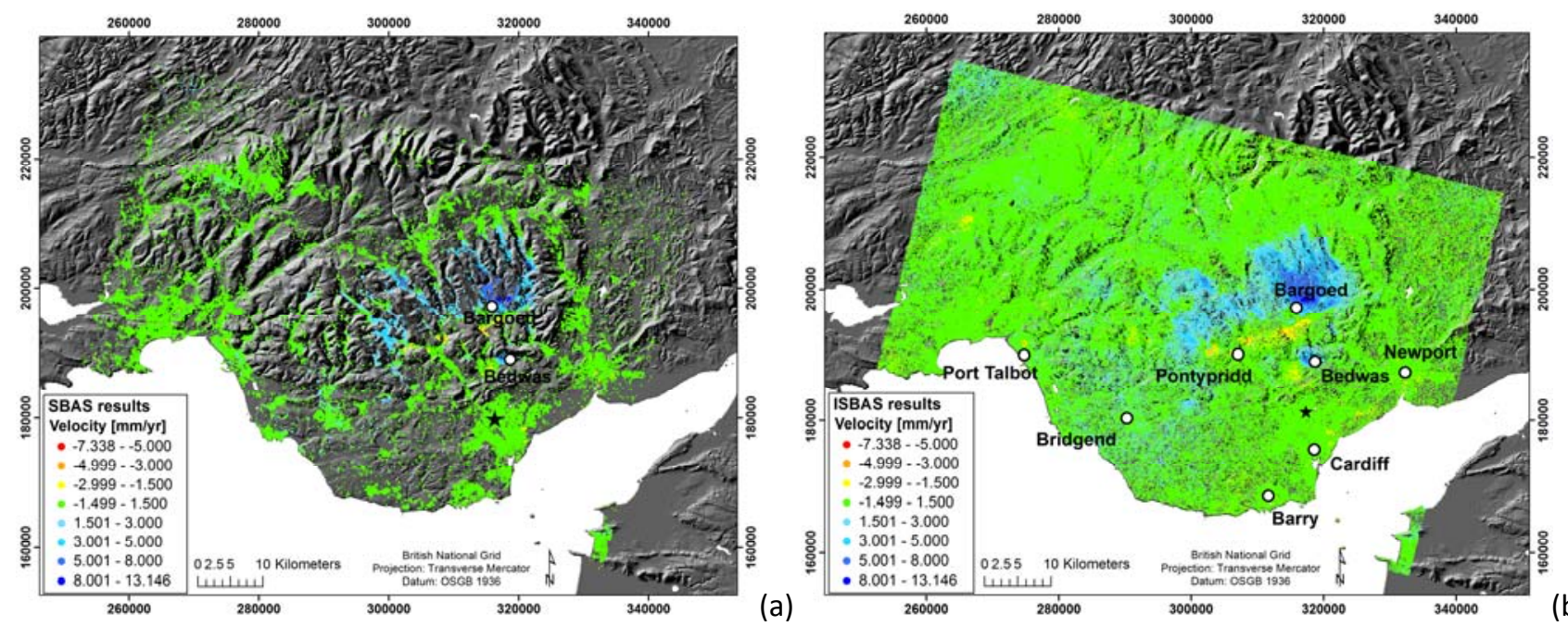

(b)

Figure 4: (a) SBAS and (b) ISBAS ERS-1/2 results for the South Wales Coalfield area, showing average rates of ground motion between 1992 and 1999, overlapped onto hillshade of NEXTMap DTM at 50m resolution (NEXTMap ${ }^{\circledR}$ Britain elevation data from Intermap Technologies). Location of the reference point is indicated with a black star.

The increase in spatial coverage afforded by the ISBAS approach offers significant advantages for the interpretation of ground motion. The improved density allows the identification of small areas of motion which fall in the gaps of the SBAS result, but it also allows the edges of displacement areas to be more accurately defined (and interpreted). This makes it easier to relate the results to other datasets and hence increases our understanding of the ground motion. Figure 6 shows an example of SBAS and ISBAS results related to the surface faulting.

\subsection{Surface uplift}

It is thought that uplift areas relate to mine water rebound prior to and during the observation period. During the period of coal extraction the majority of subsidence is due to collapse of workings, but additional subsidence is caused by the loss of pore pressure caused by dewatering which increases effective stress and causes consolidation and compaction, particularly clays and to a lesser extent in mudstones, loose silts and sands.

Subsequent re-pressuring of the aquifers through mine water rebound may cause an increase in pore water pressure, reduction in effective stress and elastic rebound, but only a fraction of the original subsidence. The main cause of the uplift is likely to result from a combination of factors such as volume increase due to decompression of the matrix of the Coal Measures aquifer and swelling of clay and mudstone materials with increasing water content. 
The location of the uplift therefore relates to the structural configuration and physical properties of rock types in the South Wales Coalfield, the quality and depth of the coal resource, the timing of coal extraction and the requirement to pump water. The next sections explain these relationships.

\subsection{Observed uplift}

The majority of uplift occurs in the east of the coalfield, the area to the west of the Neath Valley Disturbance is relatively stable. The uplift observed in the eastern coalfield appears to be related to the structure of the coalfield (Figure 5). The smaller area of uplift near Bedwas is located on the axis of the Llantwit-Caerphilly syncline, while the Bargoed uplift is on the flank of the Gelligaer syncline close to the deepest part of the eastern basin (Figure 1). Uplift therefore corresponds to areas of deeper coal worked from valley based collieries in the late $21^{\text {st }}$ Century.

The area of uplift around Bargoed, detailed in Figure 6, coincides with the extent of surface faults. There appears to be a relationship between these orientations and marked changes in uplift rate (Figure 6). It is thought that faults delineate the motion, particularly to the south and west, but these are not accommodating the motion. In the Bedwas, changes in uplift rate are coincident with the location of the faults (Figure 6).

Directly northwest of Bargoed the uplift rate decreases gradually 'up dip' of the beds on the northern limb of the syncline (Figure 5). This gradual change in uplift rate may be a consequence of the increased distance from the Bargoed cone of depression in relatively laterally homogenous and lesser faulted aquifer block. 


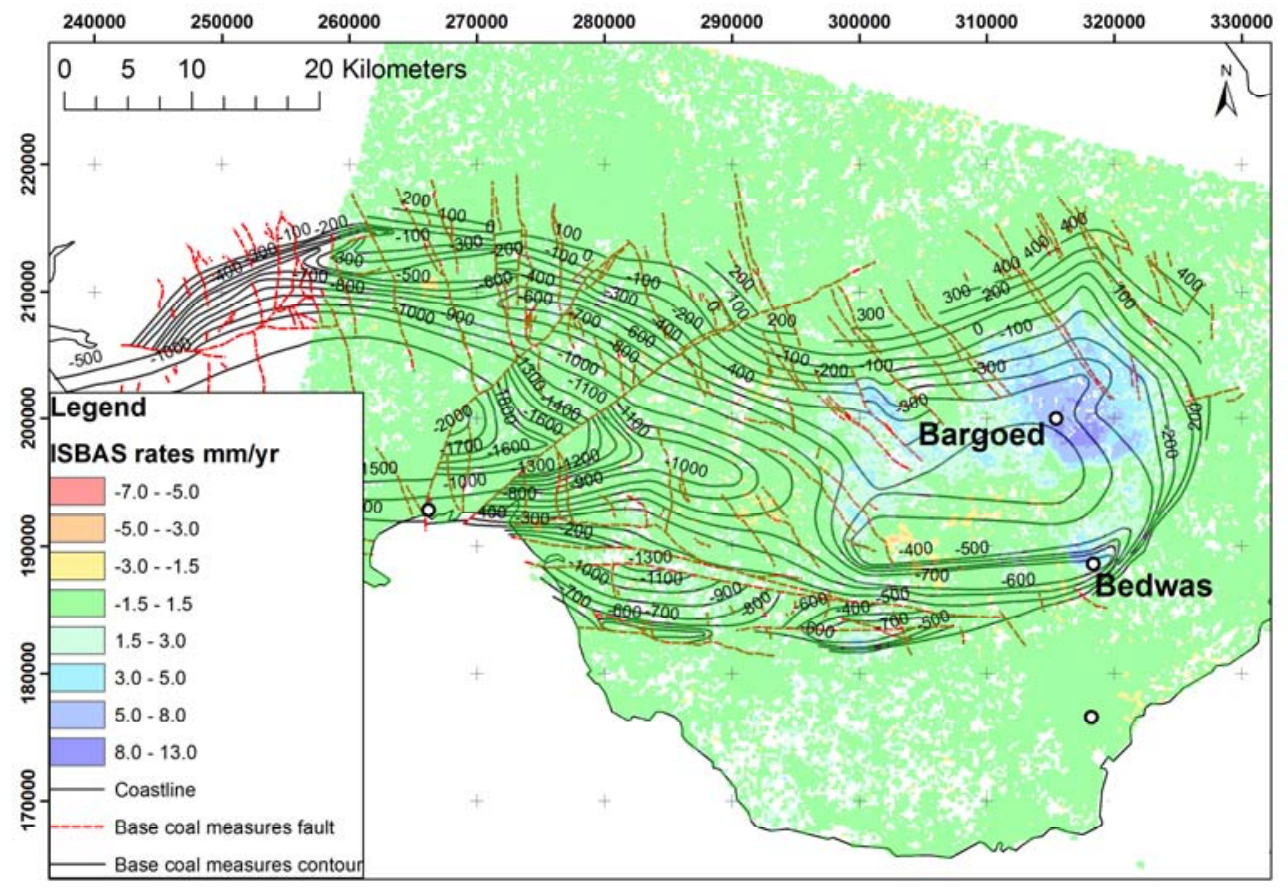

Figure 5: Location of uplift in relation to the deep structure of the South Wales Coalfield. Contains Ordnance Data (C) Crown Copyright and database rights 2013. Ordnance Survey Licence no. 100021290.
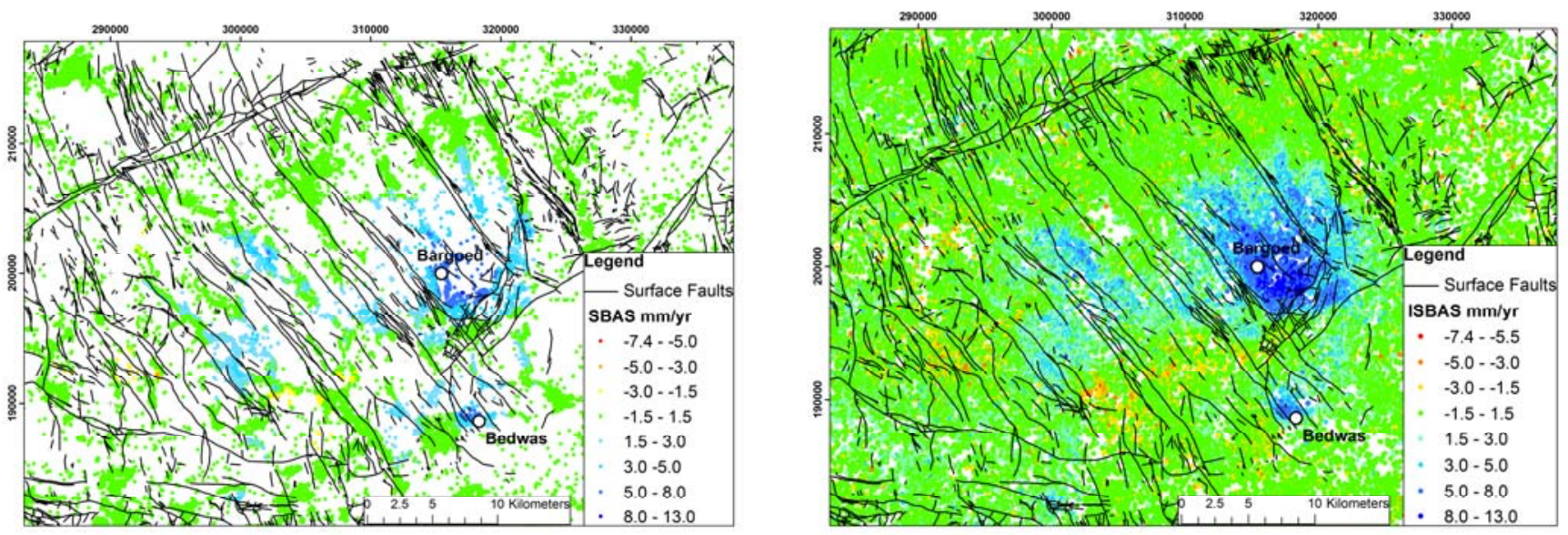

(a)

(b)

Figure 6: a) SBAS results and b) ISBAS results and mapped surface faults (Faults from DIGMapGB-50 (C2013 NERC).

\subsection{Relationship of uplift and the timing of extraction}

The South Wales Coalfield has been mined throughout history (as discussed in section 1), early mining took place towards the edges of the coalfield and progressed towards the centre; it is within the centre that we observe the maximum uplift rates in the 1990's. From 1760 onwards industrial mining took place in the north-east of the coalfield [31]. It targeted the primary and secondary coal resources, which are characterised by thick closely spaced 
coal and thin widely spaced continuous coals respectively (Figure 2). Coal mining at this time was driven by the Iron industry. It was not until the mid 1800's, when there was huge demand for coal to drive the steam engines of the industrial revolution, that the centre of the coal field, where uplift is now observed, started to be developed. Here the coal is deeper, and the seams are thinner, wider spaced and often discontinuous and interrupted by displacement along faults. A strong incentive was therefore required to develop this resource and coal production peaked during the First World War but continued, albeit in decline, in to the 1990's [31].

By the early 1990's only 5 collieries remained active [32]. Analysis of colliery closure dates show that areas of maximum uplift are coincident with mines that closed in the 1980's such as the Oakdale, Waterloo and Markham system and Bedwas (Figure 7). Interestingly areas of lower uplift rates are associated with mines that closed in the 1960's, such as the Cambrian, Naval, Bwillfa and Aberaman collieries to the west of the eastern crop (Figure 7).

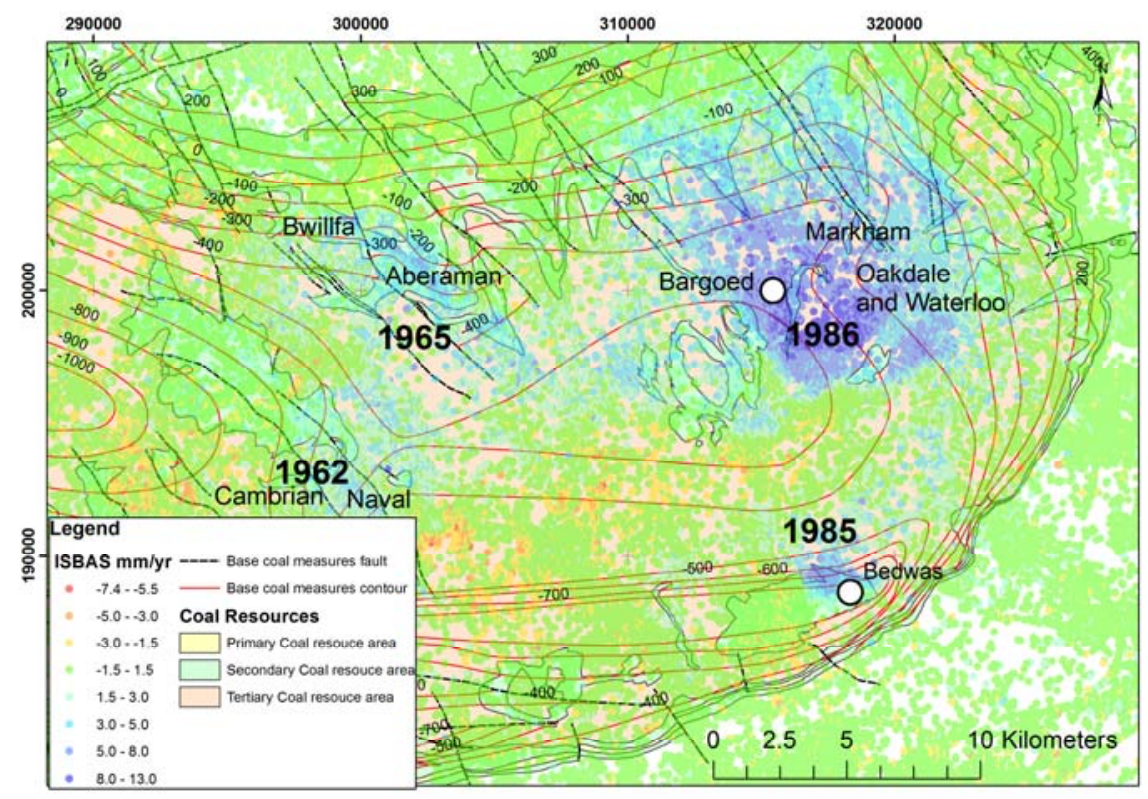

Figure 7: Uplift rates in the eastern crop imposed on an image showing the depth to the base of the coal measures (Meters below OD).

\subsection{Water pumping}

Although the coalfield to the east of the Neath Disturbance is shallower than to the west, it is wetter; there was an increased need to pump ground water to prevent it affecting the mines [27]. The coalfield thins towards the east and the deep faulted valleys found in this area allow greater recharge of the shallower coal measures. Pumping of 
active mine workings in the eastern area was therefore necessary for the safe operation of the mines, this was not as necessary to the west where lower relief and shallower mines kept the collieries dryer. As a result groundwater pumping rates for the 1949 to 1964 period significantly increase to the east of the coalfield. In fact east of a line drawn between Rhymney and Caerphilly there was a heightened risk of water inrush to the mine workings than in other areas within the coalfield. In this zone mine dewatering was able to reach high enough pressures that a burst could occur [27].

Pumping locally affected the groundwater system, groundwater levels were only depressed in the immediate area around the mine or group of interconnected mines. Thirteen mine water ponds (or blocks) have been defined [19], hydraulic interconnection exists within a pond, and therefore pumping within a mine will affect the water levels within adjacent mines the fall within the same pond. Adjacent ponds are separated until mine water reaches a given height when it starts to flow into the adjacent groundwater pond.
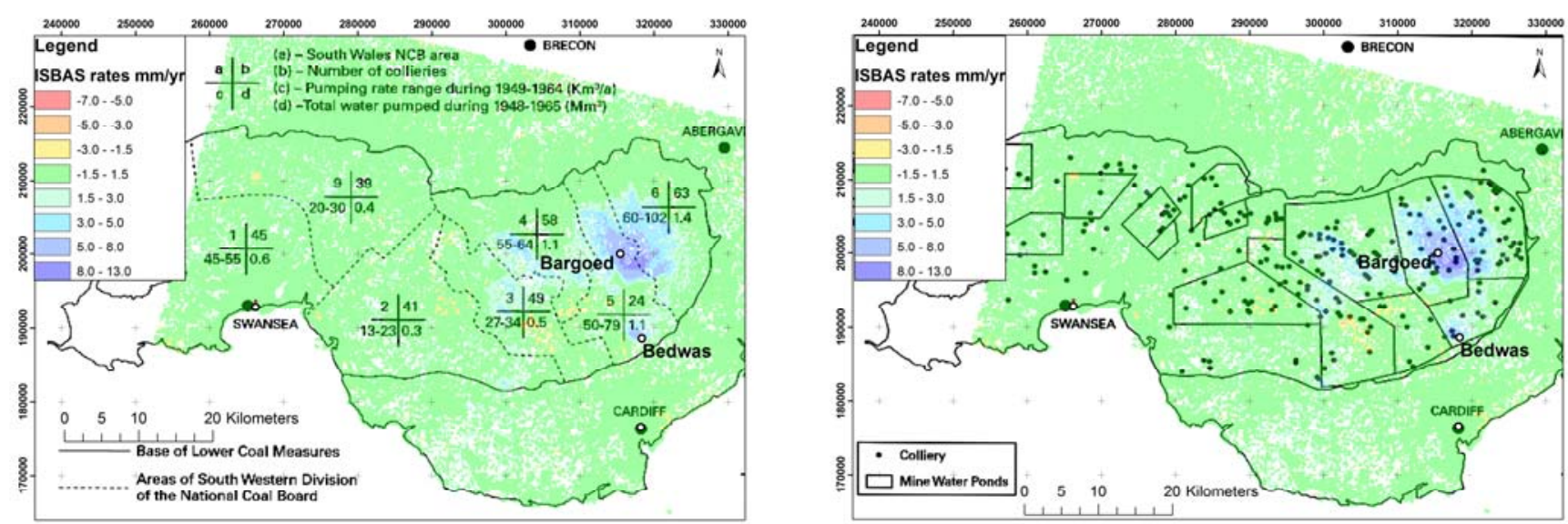

(a)

Figure 8: ISBAS results overlain on pumping rate statistics of the former National coal board areas (a) and hydraulic ponds present within the coalfield. (b). Both images modified from [27].

A relationship exists between the observed uplift, rates of pumping and defined mine water ponds; ponds with higher pumping rates in the 1949-1964 period exhibit higher uplift rates within the 1990's (Figure 8). The highest uplift rates are seen in the ponds at the eastern end of the coalfield, with maximum uplift observed within the Bargoed pond. The eastern most pond has the second highest uplift rate and might represent mine water flow from the Bargoed pond into its eastern neighbour. The Bedwas uplift is constrained to the western boundary of the pond 
in which it sits. The more diffuse uplift observed to the west of the main uplift hotspot is effectively constrained by two further mining ponds.

Similarities exist with observations of ground motion in the Northumberland coalfield during the 2000's [1]. Here uplift was also shown to be bounded by mining ponds (blocks), analysis of ground motion histories showed that the timing of uplift in each block followed the order in which water was thought to flow from one block to the next. These areas of uplift can therefore be attributed to an increase in pore water pressure brought about by the rebound of mine water levels following the cessation of pumping.

Due to the poor hydraulic interconnection of the eastern coalfield it is assumed that higher pumping rates lead to a greater rebound of mine/groundwater levels following the cessation of pumping. Mine water rebound rates will therefore be greatest within the ponds in which more water was extracted and recharge rate is high. Considering that an increase in mine water levels leads to an increase in pore water pressure, the above mechanism explains the observed higher rates of uplift within the eastern most mine water ponds.

\section{CONCLUSIONS}

InSAR is an effective tool for monitoring former coalfields. The ISBAS implementation of the technique increases its usefulness for rural areas, such as those present over many UK coalfields, where loss of coherence results in more limited results compared with more conventional methods.

Many of the expected ground motions in South Wales were identified by our ISBAS analysis for the seven year period between 1992 and 1999. The most striking of which is a large area of uplift, to the north of Cardiff in the eastern end of the South Wales Coalfield. This relates to the recovery of ground water levels following the cessation of mine water pumping which was necessary during active mining. In the absence of pumping data it is difficult to accurately infer previous mine water levels but it is assumed (drawing comparisons with the Northumberland coalfield [1]) that pumps were turned off in the early 1990's leading to a steady rise in mine water levels. The regional patterns of uplift show a similar spatial and temporal pattern to those observed in other UK coalfields following their closure [1] [30]. ENVISAT ASAR imagery from 2002 to 2009 will allow us to see if the pattern of motion persists after the 1990's. 
Ground motion in the South Wales Coalfield has implications for modelling mine water rebound and hence locations of discharge and pollution. Although the observed uplift is fairly evenly distributed, and should not cause significant building damage, city region scale deformation of this scale may impact long infrastructure such as drainage networks, pipelines, and other sensitive structures. Both groundwater rise and associated uplift may cause differential extensional and compressive ground strains that can dilate fractured rock masses, opening fissures and joints, altering hydraulic pathways and causing ground rupture along pre-existing faults. These factors may also affect slope stability and all are relevant to landslide management and land use planning, development and regeneration in the region [29].

\section{Acknowledgements}

The authors gratefully acknowledge Kevin Northmore, formally of BGS, for his support in in the selection of the study area and useful geological discussions and Katy Mee (BGS) for supplying a model of the base of the coal measures. This research is funded by BGS/NERC via the OF55 FY12-13 project "Assessing the feasibility of EO technologies (InSAR) for nationwide monitoring of geohazards in GB: first applications to landslide hazards", and supported by ESA with the provision of ERS-1/2 SAR data via the Category-1 project id.13543 "Enhancing landslide research and monitoring capability in Great Britain using C-band satellite SAR imagery and change detection, InSAR and Persistent Scatterers techniques". We acknowledge the chair of Astrodynamics and Space Missions and the ESA/REAPER project for providing recomputed orbit solutions for ERS-1/2 data.ERS data processing was carried out using the GAMMA SAR and Interferometry Software and MATLAB, both licensed to BGS/NERC, and Punnet and the ISBAS code developed at the University of Nottingham, United Kingdom. Dr David Schofield is thanked for his comments on the manuscript. This paper is published with permission of the Executive Director of BGS, NERC.

\section{REFERENCES}

[1] Banton, C., Bateson, L., McCormack, H., Holley, R., Watson, I., Burren, R., Lawrence, D., \& Cigna, F. (2013). Monitoring post-closure large scale surface deformation in mining areas. In, Mine Closure 2013. A.B. Fourie and M. Tibbett (eds). Australian Centre for Geomechanics, Perth. In press.

[2] Berardino, P., Fornaro, G., Lanari, R. \& Sansosti, E. 2002. A new algorithm for surface deformation monitoring based on small baseline differential SAR interferograms. IEEE Transactions on Geoscience and Remote Sensing, 40 (11), $2375-2383$. 
[3] Brabham. P. 2001. The rise and fall of the South Wales Coalfield. In Engineering Geology of Classic Formations: The Coal Measures, a South Wales perspective. Geological Society South Wales Regional Group and Engineering Group seminar. 10 October 2001. p2.

[4] Chen C.W. \& Zebker H.A., 2002. Phase unwrapping for large SAR interferograms: Statistical segmentation and generalized network models. IEEE Transactions on Geoscience and Remote Sensing, 40, 1709-1719.

[5] Cigna, F., Bateson, L., Jordan, C., \& Dashwood, C., 2012. Feasibility of InSAR technologies for nationwide monitoring of geohazards in Great Britain. In, Remote Sensing and Photogrammetry Society (RSPSoc) - Annual Conference 2012. London, UK. pp. 1-4.

[6] Cigna, F., Bateson, L., Jordan, C., \& Dashwood, C., 2013. Nationwide monitoring of geohazards in great britain with InSAR: feasibility mapping based on ERS-1/2 and ENVISAT imagery. IEEE International Geoscience and Remote Sensing Symposium (IGARSS), 21-26 July 2013, Melbourne, Australia, pp. 672-675.

[7] Cigna, F, Rawlins, B G, Jordan, C J, Sowter, A and Evans, C. 2014. Intermittent Small Baseline Subset (ISBAS) InSAR of rural and vegetated terrain: a new method to monitor land motion applied to peatlands in Wales, UK. EGU General Assembly 2014, Vienna (Austria), 27 April - 02 May 2014. Geophysical Research Abstracts, Vol. 16, EGU2014-3844-1, 2014.

[8] Cigna, F., Bateson, L., Jordan, C. and Dashwood, C., (in press). Simulating SAR geometric distortions and predicting Persistent Scatterer densities for ERS-1/2 and ENVISAT C-band SAR and InSAR applications: nationwide feasibility assessment to monitor the landmass of Great Britain with SAR imagery. Remote Sensing of Environment, doi: 10.1016/j.rse.2014.06.025

[9] Caro Cuenca, M., Hooper, A. J., \& Hanssen, R. F. (2013). Surface deformation induced by water influx in teh abandoned coal mines in Limburg, the Netherlands observed by satellite radar interferometry. Journal of Applied Geophysic, 88, 1-11.

[10] Crosetto, M., Monserrat, O., Iglesias, R., \& Crippa, B. (2010). Persistent Scatterer Interferometry: Potential, Limits and Initial C- and X-band Comparison. Photogrammetric Engineering and Remote Sensing, 76, 1061-1069

[11] Culshaw, M., Tragheim, D., Bateson, L., \& Donnelly, L. (2006). Measurement of ground movements in Stoke-on-Trent (UK) using radar interferometry. In C.e. al. (Ed.), 10th Congress of the International Association for Engineering Geology and the Environment, IAEG2006 (pp. 1-10). Nottingham, UK: Geological Society, London.

[12] Donnelly, L.J. 2006. A review of coal mining induced fault reactivation in Great Britiain. Quaterly Journal of Engineering Geology and Hydrogeology 39, p5-50.

[13] EEA (2007). CLC2006 technical guidelines. European Environment Agency (EEA) Technical report No.17/2007, (p. 70). Available at: http://www.eea.europa.eu/publications/technical_report_2007_17. 
[14] Farr, T.G., Rosen, P.A., Caro, E., Crippen, R., Duren, R., Hensley, S., Kobrick, M., Paller, M., Rodriguez, E., Roth, L., Seal, D., Shaffer, S., Shimada, J., Umland, J., Werner, M., Oskin, M., Burbank, D., \& Alsdorf, D. (2007). The Shuttle Radar Topography Mission. Reviews of Geophysics, 45, RG2004.

[15] Howells, M F. 2007. British Regional Geology: Wales. British Geological Survey, Keyworth, Nottingham, UK.

[16] Jones. D.B., Siddle, H.J. 2000. In: Siddle, H.L., Bromhead, E.N. and Bassett, M.G. (eds). 2000. Landslides and landslide management in South Wales. Chapter 8 p40-43. National Museum of Wales, Geological Series No. 18, Cardiff

[17] Jordan, H., Cigna, F. and Bateson, L., 2013. GeoHazard Description for Stoke-On-Trent, Version 1.0. Available at: http://www.pangeoproject.eu/pdfs/english/stoke/Geohazard-Description-stoke.pdf, 122 pp.

[18] Lanari, R., Mora O., Manuta M., Mallorqui J.J., Berardino P. \& Sansosti E., 2004. A smallbaseline approach for investigating deformations on full-resolution differential SAR interferograms. IEEE Transactions on Geoscience and Remote Sensing. 42 (7). 1377-1386.

[19] Lewis, B.J., Leighfield, K.G. \& Cox, S.J. 2000. The South Wales Coalfield (including the Pembrokeshire Coalfield): A review of mine water recovery. Report from Wardell Armstrong for Coal Authority, Job NL02906.

[20] Mather, J.D. 2000. The influence of mining subsidence on the hydrogeology of Cardoniferous sandstones at Aberfan. In: Siddle, H.L., Bromhead, E.N. and Bassett, M.G. (eds). 2000. Landslides and landslide management in South Wales. Chapter 8 p22-25. National Museum of Wales, Geological Series No. 18, Cardiff

[21] National Coal Board. 1960. South Wales Coalfield Seam Maps, 1957-1962. GB0218.D3561.

[22] Nichols, Jr. T.C. Rebound, its nature and effect on engineering works. 1980. Quarterly Journal of Engineering Geology. 13 133-152.

[23] Northmore, K. \& Donnelly, L. 2013. Personnel Communication.

[24] Novellino A., Athab A.D., bin Che Amat M.A., Syafiudin M.F., Sowter A., Marsh S., Cigna F., Bateson L. 2014a. Intermittent SBAS ground motion analysis in low seismicity areas: case studies in the Lancashire and Staffordshire coalfields, UK. Seismology from Space: Geodetic observations and early warning of earthquakes. Royal Astronomical Society, Burlington House, Piccadilly, London, UK.

[25] Novellino, A, Cigna, F, Jordan, C, Sowter, A and Calcaterra, D. 2014b. Monitoring large-scale landslides and their induced hazard with COSMO-SkyMed Intermittent SBAS (ISBAS): a case study in north-western Sicily, Italy. EGU General Assembly 2014, Vienna (Austria), 27 April - 02 May 2014. Geophysical Research Abstracts, Vol. 16, EGU2014-9621, 2014. 
[26] Rawlins, B, Cigna, F, Jordan, C, Sowter, A, Evans, C, Robinson, D, and The GMEP Team. 2014. Monitoring changes in surface elevation of blanket peat and other land cover types using a novel InSAR processing technique. EGU General Assembly 2014, Vienna (Austria), 27 April - 02 May 2014. Geophysical Research Abstracts, Vol. 16, EGU2014-3047, 2014.

[27] Robins, N.S., Davies J., \& Dumpleton. S.2008. Groundwater flow in the South Wales coalfield: historical data informing 3D modelling. Quarterly Journal of Engineering Geology and Hydrogeology, 41, 477-486.

[28] Rudenko, S., Otten, M., Visser, P., Scharroo, R., Schoene, T., Esselborn, S. New improved orbit solutions for the ERS-1 and ERS-2 satellites. Advances in Space Research, 49, 8, 1229-1244, doi:10.1016/j.asr.2012.01.021, 2012.

[29] Siddle, H.L., Bromhead, E.N. and Bassett, M.G. (eds). 2000. Landslides and landslide management in South Wales. 116pp. National Museum of Wales, Geological Series No. 18, Cardiff.

[30] Sowter A., Bateson L., Strange P., Ambrose K., Syafiudin M., 2013. DInSAR estimation of land motion using intermittent coherence with application to the South Derbyshire and Leicestershire coalfield. Remote Sensing Letters, 4 (10), $979-987$.

[31] Sowter A., Bateson L., Cigna F., Syafiudin Moh F. 2013. InSAR everywhere: using the ISBAS method to identify slow land surface deformation in rural and vegetated areas. The 2013 3rd International Workshop on Image and Data Fusion (IWIDF 2013), 9-11 August 2011, Tengchong, Yunnan, China, 20-22 August 2013, Changbaishan, Antu, China.

[32] Statham, I., \& Treharne, G. 1991. Subsidence due to abandoned mining in the South Wales Coalfield, UK; causes, mechanisms and environmental risk assessment. Land Subsidence (proceedings of the Fourth International Syumposium on Land Subsidence, may 1991). IAHS publ.no.200.

[33] Terzaghi. K, Peck. R, B., Mesri. G. 1996. Soil Mechanics in Engineering Practice. Third Edition. John Wiley \& Sons, Inc.

[34] Walsby, J.C., 2008. Geosure: a bridge between geology and decision making. In: D.G.E. Liverman, C.P.G. Pereira and B. Marker (Editors), Communicating Environmental Geoscience. Geological Society, London, UK, pp. 81-87. 